Quim. Nova, Vol. 28, No. 2, 296-305, 2005

\title{
APLICAÇÃO DE LIPASES NO TRATAMENTO DE ÁGUAS RESIDUÁRIAS COM ELEVADOS TEORES DE LIPÍDEOS
}

\author{
Adriano Aguiar Mendes e Heizir Ferreira de Castro* \\ Departamento de Engenharia Química, Faculdade de Engenharia Química de Lorena, CP 116, 12606-970 Lorena - SP \\ Ernandes Benedito Pereira e Agenor Furigo Júnior \\ Departamento de Engenharia Química e Engenharia de Alimentos, Universidade Federal de Santa Catarina, CP 476, \\ 88040-900 Florianópolis - SC
}

Recebido em 12/12/03; aceito em 14/9/04; publicado na web em 4/2/05

\begin{abstract}
APPLICATION OF LIPASES FOR WASTEWATER TREATMENT CONTAINING HIGH LEVELS OF LIPIDS. The process of anaerobic digestion has been greatly developed during the last decades for the treatment of wastewater from food industries as for example, wastewaters from sugar and starch manufacturing and from breweries. However, for wastewaters which contain high amounts of fats and proteins, such as those from slaughterhouses and dairies, anaerobic digestion was found to be troublesome, due to the potential of sludge flotation, the formation of scum layers of lipids at the surface of the reactor, which are not digested and the toxicity of the intermediate compounds (long chain fatty acids) generated during the anaerobic digestion of the wastewater. The addition of hydrolytic enzymes, such as lipases prior to the anaerobic digestion can minimize these problems. In this work, this strategy is reviewed and the technical issues that must be considered in determining its feasibility are discussed.
\end{abstract}

Keywords: wastewater; lipids; lipase and enzymatic treatment.

\section{INTRODUÇÃO}

A adoção de um maior rigor nos padrões de descarte de águas residuárias tem motivado a realização de pesquisas, cujo objetivo é reduzir o impacto ambiental, especialmente em efluentes contendo elevados teores de lipídeos, como os provenientes de laticínios, matadouros e avícolas, enlatados, extração de óleos, entre outros. A Política Nacional de Recursos Hídricos, instituída pela Lei Federal $\mathrm{n}^{\circ} 9.433$ de 8 de janeiro de 1997 trata da cobrança pelo uso dos corpos d'água para o lançamento de despejos líquidos.

Os lipídeos contidos nesses efluentes, além de representarem uma perda industrial importante, interferem negativamente nos Sistemas de Tratamento de Efluentes. Elevadas concentrações de lipídeos resultam na formação de lodos com diferentes características físicas e reduzida atividade hidrolítica devido à flotação dessa biomassa, aumento do tempo de retenção hidráulica desses efluentes nas lagoas de estabilização, redução da capacidade de aeradores e elevada demanda de produtos floculantes ${ }^{1}$.

Dentro deste contexto, processos alternativos vêm sendo utilizados na redução da concentração de lipídeos contidos nesses efluentes por meio de ação de enzimas, particularmente lipases. Essas enzimas apresentam uma importância particular, pelo fato de hidrolisarem especificamente óleos e gorduras, o que pode ser de grande interesse para o tratamento de efluentes com alto teor de gordura. As lipases (triacilglicerol acil hidrolases, E.C.3.1.1.3) compreendem um grupo de enzimas hidrolíticas que atuam na interface orgânica-aquosa, catalisando a hidrólise de ligações éster-carboxílicas, presentes em acilgliceróis ${ }^{2}$. A sua utilização reduz os níveis de sólidos suspensos e lipídeos, o que possibilita melhores condições de operação no tratamento anaeróbio e desobstrui filmes de óleos em tubulações, resultando no aumento da vida útil dos equipamentos.
Além disso, esse tratamento apresenta algumas vantagens, tais como a especificidade que permite controlar os produtos, o que leva a um aumento dos rendimentos pela não geração de subprodutos tóxicos; condições moderadas de operação, redução do custo em termos de energia e de equipamentos, tornando este processo atrativo sob o ponto de vista ambiental ${ }^{3}$. O objetivo do presente trabalho é descrever a ação de enzimas hidrolíticas, especificamente lipases, no pré-tratamento de águas residuárias com elevado teor de lipídeos, provenientes das indústrias do setor agroindustrial e domésticos. Os aspectos técnicos que devem ser considerados para aplicação desse tratamento são discutidos.

\section{TRATAMENTO DE EFLUENTES}

O volume e a concentração dos despejos industriais variam dentro de amplos limites, dependendo dos processos de fabricação empregados e dos métodos de controle dos despejos. Com isto, a caracterização de efluentes é uma tarefa básica para o equacionamento adequado do problema de tratamento. É nessa etapa que são obtidas informações quanto à composição e vazão da água residuária, levando em conta suas variações ao longo do tempo, em função das atividades responsáveis por sua geração. Com base nessas informações, podem ser adotados métodos físicos, químicos ou biológicos no tratamento de efluentes ${ }^{4}$.

Os métodos físicos de tratamento abrangem a remoção de sólidos de dimensões relativamente grandes, de sólidos em suspensão, areias e lipídeos. Para essa finalidade são utilizadas grades, peneiras simples ou rotativas, caixas de areia ou tanques de remoção de óleos e graxas, decantadores, filtros de areia. As grades destinam-se a reter sólidos grosseiros em suspensão e são utilizados para a proteção de bombas, válvulas e outros equipamentos. Peneiras são dispositivos destinados à retenção de partículas mais finas. As caixas de areia destinam-se a retenção de detritos pesados inertes, em suspensão nas águas residuárias e são usadas para proteger bombas e tubulações contra abrasão e entupimento. Os tanques de decantação são 
empregados na separação de sólidos sedimentáveis contidos em águas residuárias ${ }^{5}$.

Na remoção de lipídeos em estado livre, geralmente são utilizadas caixas de gordura comuns que permitem sua separação por retirada manual ou por meio de raspadores na superfície. Para melhor desempenho dessas caixas, devem ser evitadas temperaturas superiores a $35^{\circ} \mathrm{C}$ e pH acima de 8,5 na alimentação da caixa, pois nessas condições ocorre a saponificação ou emulsificação e o excesso de detergentes prejudica a eficiência de separação pela formação de gotículas de menor tamanho, com menor velocidade ascensional ${ }^{6}$. No caso de formação de emulsão, esta deve ser quebrada pela adição de produtos químicos e utilização de flotadores com ar dissolvido. Apesar da eficiência de remoção melhorar significativamente, a flotação apresenta custos operacionais elevados, além de gerar lodo químico, que deve ter uma destinação adequada.

Os métodos químicos são utilizados para remover material coloidal, cor e turbidez, odor, ácidos, álcalis, metais pesados e óleos. A neutralização de despejos industriais pode ser necessária, não só para se evitar o lançamento de águas ácidas ou alcalinas no corpo de água receptor, mas também, como medida necessária para proteção.

Os processos físico-químicos permitem uma remoção parcial de sólidos totais, com o emprego de compostos como sulfato de alumínio, cloreto férrico e sulfito ferroso ${ }^{7}$. Entretanto, os reagentes químicos empregados são de custos elevados e a remoção de sólidos dissolvidos é bastante reduzida. A remoção de sólidos dissolvidos é realizada por processos biológicos ${ }^{8}$.

Os processos biológicos dividem-se em aeróbios e anaeróbios ${ }^{9}$. Os sistemas biológicos de tratamento de resíduos devem atender alguns aspectos importantes: (1) remoção da matéria orgânica, portanto redução da Demanda Bioquímica de Oxigênio (DBO) do resíduo a ser tratado; (2) se possível, degradação de compostos químicos orgânicos de difícil degradação (recalcitrantes); (3) fornecimento de um efluente em condições que não afete o equilíbrio do sistema receptor final (rios e lagos). A Tabela 1 fornece alguns exemplos de águas residuárias potencialmente tratáveis por processos biológicos, bem como os valores de DBO dos rejeitos.

Nos processos aeróbios a estabilização dos despejos é realizada por microrganismos aeróbios e facultativos; nos processos anaeróbios os microrganismos atuantes são os facultativos e anaeróbios. Os processos aeróbios podem ser lodos ativados, filtro biológico, lagoa de estabilização aeróbia, entre outros.

Nos processos anaeróbios de tratamento de despejos, a decomposição da matéria orgânica é conseguida na ausência de oxigênio molecular. Esta degradação refere-se às reações que reduzem as dimensões de partículas, tornando-as solúveis ou, em nível molecular, quebram cadeias ou ligações triplas ou duplas existentes. Os produtos finais do processo são metano e compostos inorgânicos, incluindo o dióxido de carbono, ácido sulfídrico e amônia ${ }^{11}$. A Tabela 2 apresenta os sistemas biológicos a serem adotados com a finalidade de estabilização da matéria poluente. O sucesso da aplicação de cada um deles está relacionado com o conhecimento prévio do efluente a ser tratado, e da eficiente operação dos reatores na manutenção da atividade microbiana e das reações de mineralização desejadas.

Os principais microrganismos empregados no processo anaeróbio são as bactérias ${ }^{14}$. A capacidade de uma bactéria anaeróbia decompor um determinado substrato é bastante específica, dependendo principalmente das enzimas que possui. As enzimas, responsáveis pelas reações do processo de decomposição, apresentam alto grau de especificidade. A eficiência global de conversão da matéria orgânica em produtos estabilizados depende da eficiência de cada reação e do equilíbrio entre as diversas espécies e entre os grupos de bactérias presentes no sistema anaeróbio ${ }^{15}$.

Ao contrário dos processos aeróbios, os processos anaeróbios não necessitam de equipamentos de aeração artificial e há geração de biogás $\left(\mathrm{CH}_{4}\right)$, que pode ser aproveitado na indústria como fonte de energia. $\mathrm{O}$ processo anaeróbio possui baixa produção de biomassa, apenas 10 a $20 \%$ do volume produzido no aeróbio, devido à reduzida taxa de crescimento dos microrganismos no consórcio anaeróbio ${ }^{16}$. Dentre os diversos tipos de reatores anaeróbios utilizados, o reator de leito de lodo anaeróbio de fluxo ascendente (UASB) é o mais

Tabela 1. Valores de Demanda Bioquímica de Oxigênio (DBO) para diferentes tipos de águas residuárias

\begin{tabular}{lc}
\hline Águas residuárias & DBO (mg/L) \\
\hline Esgotos sanitários & $200-600$ \\
Efluente de alimentos - enlatados & $500-2.000$ \\
Efluente de cervejarias & $500-2.000$ \\
Efluente de processamento de óleo comestível & $15.000-20.000$ \\
Efluente de destilaria de álcool (vinhaça) & $15.000-20.000$ \\
Percolado de aterros sanitários (chorume) & $15.000-20.000$ \\
Efluente de matadouros (sem recuperação & 30.000 \\
de resíduos) & $40-48.000$ \\
Efluente de laticínios (sem recuperação de & \\
soro de queijo) & \\
\hline
\end{tabular}

Fontes: refs. 4 e 10.

Tabela 2. Sistemas biológicos e funções específicas

Sistemas biológicos Funções

Lagoas de estabilização

Fornecimento natural de oxigênio pelo desenvolvimento de algas em lagoas construídas para a degradação microbiana de compostos orgânicos poluentes, e conversão a dióxido de carbono e água

Lodos ativados, filtros biológicos, lagoas aeradas e valas de oxidação
Degradação microbiana de compostos orgânicos poluentes por meio do metabolismo aeróbio, facilitado pela disponibilidade artificial de oxigênio em reatores ou em lagoas, e conversão a dióxido de carbono e água

\begin{tabular}{ll}
\hline Sistemas de nitrificação & Conversão de compostos orgânicos nitrogenados e amônia a nitratos \\
\hline $\begin{array}{l}\text { Sistemas de desnitrificação } \\
\begin{array}{l}\text { Sistema alternado anóxico e aeróbio para } \\
\text { remoção de nutrientes }\end{array}\end{array}$ & Remoçãão de nutrientes, particularmente de fosfatos \\
\hline Biodigestão anaeróbia & $\begin{array}{l}\text { Degradação microbiana de compostos orgânicos a ácidos orgânicos, álcoois, hidrogênio, } \\
\text { dióxido de carbono e metano }\end{array}$
\end{tabular}

Fontes: refs. 12 e 13. 
utilizado industrialmente no Brasil ${ }^{17}$. A vantagem desse reator é a habilidade de reter alta concentração de biomassa, com alta velocidade de fluxo e alta produção de biogás.

$\mathrm{O}$ reator UASB consiste, basicamente, em um tanque em cuja parte inferior está localizada a zona de digestão e na parte superior, a zona de decantação e separação do gás ${ }^{18}$. O efluente a ser tratado é uniformemente distribuído na base do reator e passa por meio da camada de lodo biológico, a qual transforma a matéria orgânica presente no efluente, principalmente, em metano e gás carbônico.

Nos reatores de leito de lodo anaeróbio de fluxo ascendente, é importante a agregação de bactérias. A formação de agregados pode ser realizada por floculação microbiana e/ou granulação ${ }^{19}$. A floculação tem sido a mais estudada, porque é o fenômeno mais comum nos reatores biológicos em geral.

\section{LIPÍDEOS}

A fração de lipídeos é caracterizada por óleos, graxas, gorduras e ácidos graxos livres e, juntamente com proteínas e carboidratos compõem os principais compostos orgânicos de águas residuárias de diversas indústrias de alimentos ${ }^{20,21}$. Lipídeos são compostos que causam grandes danos ao meio ambiente, como a formação de filmes de óleo nas superfícies aquáticas, impedindo a difusão de oxigênio do ar para esse meio e o mais importante, promovem a mortandade da vida aquática ${ }^{22}$.

Os lipídeos encontram-se, preferencialmente, na forma de triacilgliceróis e uma pequena parte como ácidos graxos de cadeia longa (AGCL) ${ }^{23}$. A presença de triacilgliceróis e AGCL é bastante similar, constituindo, aproximadamente, em $80 \%$ de ácido palmítico, esteárico, oleico e linoleico ${ }^{23}$. Dentre esses, o ácido graxo mais abundante é o ácido oleico $\left(\mathrm{C}_{18: 1}\right)^{23-24}$.

As principais fontes de geração de lipídeos são indústrias de óleos comestíveis, sorvetes, laticínios, curtumes, matadouros e os efluentes domésticos e de restaurantes, principalmente de "fast food" 25,26 . Os valores de concentração de lipídeos, nesses efluentes, são mostrados na Tabela 3. Nas estações de tratamento desses efluentes, a elevada concentração de triacilgliceróis necessita inicialmente ser hidrolisada para, em seguida, ser transformada em fonte de carbono para as bactérias e, posteriormente, ser convertido em biomassa (lodo ativado) ${ }^{32}$.

Tabela 3. Fontes de lipídeos e suas concentrações em águas residuárias

\begin{tabular}{lcc}
\hline Tipos de efluentes & $\begin{array}{c}\text { Concentração de } \\
\text { lipídeos }(\mathrm{mg} / \mathrm{L})\end{array}$ & Ref. \\
\hline Doméstico & $40-100$ & 21 \\
Matadouros e avícolas & Acima de 500 & 27 \\
Laticínios & 4.680 & 28 \\
Restaurantes & 98 & 29 \\
Azeite de oliva & 16.000 & 30 \\
Sorvetes & 845 & 31 \\
\hline
\end{tabular}

A transformação de lipídeos em lodo ativado é necessária por duas razões: os lipídeos contribuem com 30-40\% da matéria orgânica, presente nos efluentes e esses compostos estimulam o crescimento de microrganismos filamentosos, importantes na remoção de nutrientes como fósforo e nitrogênio, promovendo a sustentação do lodo formado ${ }^{32}$. Com baixa concentração desses microrganismos, a probabilidade de formação de grânulos maiores de lodo é reduzida, acarretando sua flotação ${ }^{19}$.
A transformação de lipídeos em lodo ativado, empregando a espécie microbiana Microthrix parvicella foi estudada por Dueholm et $a l .{ }^{32}$, por meio do monitoramento das taxas máximas de consumo de oxigênio e nitrogênio. Esses autores observaram que os AGCL e triacilgliceróis adsorvidos pelo lodo dificultam a quantificação de oxigênio e nitrogênio consumidos para produção de células. Além disso, observaram que a hidrólise, dos triacilgliceróis em AGCL, é uma etapa lenta e não adequada para caracterizar as taxas de oxigênio e nitrogênio consumidos. O modelo conceitual das etapas de transformação de lipídeos em lodo ativado é mostrado na Figura 1.

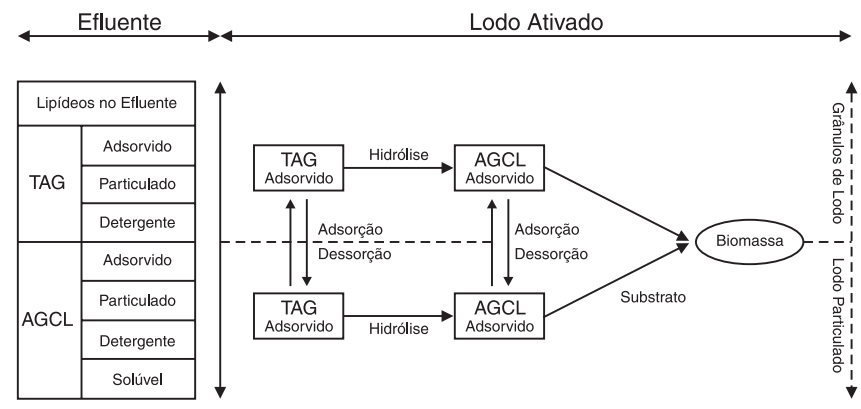

Figura 1. Etapas envolvidas na transformação de lipídeos em lodo ativado (TAG: Triacilgliceróis; AGCL: Ácidos Graxos de Cadeia Longa). Adaptada das refs. 32 e 33

\section{PROBLEMAS RELACIONADOS AOS ELEVADOS TEORES DE LIPÍDEOS NO TRATAMENTO ANAERÓBIO DE ÁGUAS RESIDUÁRIAS}

A hidrólise de lipídeos, etapa limitante na digestão anaeróbia de sólidos ${ }^{25,32}$, presentes em diversos tipos de efluentes é devido ao baixo consumo de ácidos graxos de cadeia longa pelas bactérias ${ }^{25,34} \mathrm{e}$ à necessidade de uma pequena concentração de hidrogênio $\left(\mathrm{H}_{2}\right)$, formado nas reações de encurtamento da cadeia carbônica dos AGCL. O acúmulo deste gás pode afetar o equilíbrio das reações de decomposição dos AGCL que são termodinamicamente desfavoráveis ${ }^{35,36}$. Desta forma, a acumulação de AGCL pode causar problemas na digestão anaeróbia de efluentes, como toxicidade a microrganismos acetogênicos e metanogênicos ${ }^{36,37} \mathrm{e}$ a formação de espumas, devido ao acúmulo de ácidos graxos não biodegradados ${ }^{38}$. As etapas da biodegradação de lipídeos e de outros compostos encontrados em efluentes, como proteínas e açúcares, são apresentadas na Figura 2.

Uma grande diversidade de microrganismos está envolvida na degradação anaeróbia de substratos complexos como os encontra-

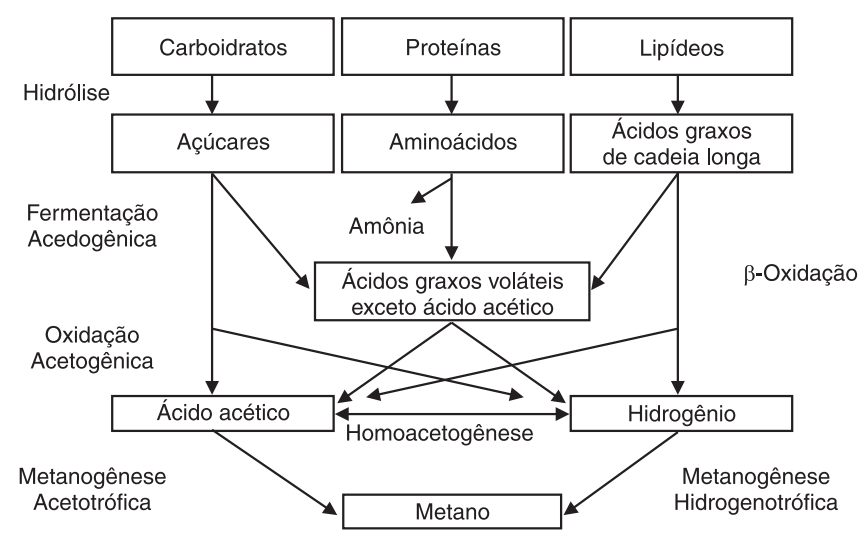

Figura 2. Etapas de degradação anaeróbia dos componentes orgânicos presentes nos efluentes. Adaptada das refs. 38 e 39 
dos em efluentes das atividades zootécnicas, como matadouros, abate de frangos, entre outras.

As condições de processamento e as etapas de operação são fatores que determinam como devem ser tratados esses efluentes. Por exemplo, os sólidos presentes em águas de matadouro são constituídos de altas concentrações de diferentes proteínas e lipídeos. Bactérias fermentativas, particularmente microrganismos do gênero proteolítico Clostridium, hidrolisam proteínas a aminoácidos e polipeptídeos, lipídeos a AGCL e glicerol e carboidratos a açúcares e álcoois. Em seguida, as bactérias fermentativas convertem esses intermediários a ácidos graxos voláteis $(\mathrm{AGV})$, hidrogênio $\left(\mathrm{H}_{2}\right)$ e gás carbônico $\left(\mathrm{CO}_{2}\right)$. Amônia $\left(\mathrm{NH}_{3}\right)$ e sulfetos $\left(\mathrm{S}^{-2}\right)$ são produzidos pela fermentação de aminoácidos. As bactérias acetogênicas convertem os AGCL, AGV com três ou mais carbonos e álcoois, superiores ao metanol, a ácido acético, $\mathrm{H}_{2}$ e $\mathrm{CO}_{2}$. Essas reações necessitam de uma concentração de $\mathrm{H}_{2}$, com pressão parcial da ordem de $10^{-3} \mathrm{~atm}$, para que bactérias metanogênicas e algumas espécies de microrganismos acetogênicos possam degradar esses intermediários. Na etapa final, as bactérias metanogênicas convertem o ácido acético, $\mathrm{H}_{2} \mathrm{e}$ $\mathrm{CO}_{2}$ a $\mathrm{CH}_{4}$ e $\mathrm{CO}_{2}$, como produtos finais ${ }^{40}$.

Os ácidos graxos de cadeia longa (AGCL) são responsáveis, também, pelo decréscimo da concentração de trifosfato de adenosina (ATP), molécula utilizada como fonte de energia pelas células microbianas ${ }^{36,41}$. Perle et $a l .{ }^{41}$ estudando o efeito dos lipídeos, provenientes de efluentes de laticínios, na redução da atividade metanogênica e concentração de ATP, constataram que a inibição das atividades fisiológicas microbianas é bastante acentuada para efluentes contendo $100 \mathrm{mg} / \mathrm{L}$ de lipídeos, em termos de produção de biogás. Para efluentes contendo concentrações acima de $500 \mathrm{mg} / \mathrm{L}$ de lipídeos, a produção do gás metano foi nula. Esses autores observaram também que as proteínas influenciam na atividade celular, testando culturas anaeróbias não-aclimatadas e pré-aclimatadas em caseína e ácido oleico, principais proteína e AGCL presentes no efluente, respectivamente. As culturas não-aclimatadas demonstraram dificuldades na degradação de compostos orgânicos e no comprometimento nas atividades fisiológicas, ao contrário das culturas pré-aclimatadas.

Dentro das células microbianas, esses ácidos são incorporados a complexos lipídicos, como a membrana plasmática ou catabolizados para a formação de compostos de baixa massa molar $\left(\mathrm{CO}_{2}, \mathrm{CH}_{4} \mathrm{e}\right.$ $\mathrm{H}_{2} \mathrm{O}$ ). As etapas determinantes, para a oxidação desses ácidos, envolvem uma série de quatro reações catalisadas por enzimas que clivam dois átomos de carbono por vez, a partir do terminal carboxílico de um ácido graxo. Essa série de reações é repetida para o encurtamento da cadeia do ácido graxo e continua até que todo o ácido seja degradado a acetil-CoA, que se converte em ácido acético e, posteriormente, em compostos de baixa massa molar, como produtos finais. A reação de degradação dos ácidos graxos é denominada de $\beta$-oxidação e o mecanismo é mostrado no esquema ${ }^{42}$ :

$$
\begin{aligned}
\mathrm{CH}_{3}\left(\mathrm{CH}_{2}\right)_{\mathrm{n}} \mathrm{COOH}+2 \mathrm{H}_{2} \mathrm{O} \rightarrow & \mathrm{CH}_{3}\left(\mathrm{CH}_{2}\right)_{\mathrm{n}-2} \mathrm{COOH}+\mathrm{CH}_{3} \mathrm{COOH} \\
& +4 \mathrm{e}^{-}+4 \mathrm{H}^{+}
\end{aligned}
$$

Para cada molécula de AGCL degradada, é formada uma molécula de ácido graxo com dois átomos de carbono a menos e uma de ácido acético, liberando quatro elétrons e quatro íons hidrogênio. Esses elétrons são transportados por aceptores no interior das células microbianas como FADH (flavina-adenina-dinucleotídeo) e NADH (nicotinamida-adenina-dinucleotídeo) e utilizados para a formação de duas moléculas de gás hidrogênio, como apresentado pela reação:

$4 \mathrm{e}^{-}+4 \mathrm{H}^{+} \rightarrow 2 \mathrm{H}_{2}$
O hidrogênio formado é, então, utilizado por microrganismos metanogênicos hidrogenotróficos para a formação de metano. Esses microrganismos não sofrem inibição pelos AGCL. Na ausência de outros aceptores de elétrons, como íons sulfato, o ácido acético formado pode ser consumido por microrganismos metanogênicos acetotróficos, pois esses microrganismos também não sofrem inibição pelos AGCL ${ }^{43}$.

Em estudos realizados por Novak e Carlson ${ }^{35}$ foi observado que o mecanismo de $\beta$-oxidação converteu, seqüencialmente, ácidos graxos saturados como esteárico $\left(\mathrm{C}_{18: 0}\right)$ para ácidos palmítico $\left(\mathrm{C}_{16: 0}\right)$, mirístico $\left(\mathrm{C}_{14: 0}\right)$, láurico $\left(\mathrm{C}_{12: 0}\right)$, cáprico $\left(\mathrm{C}_{10: 0}\right)$ e outros a ácido acético, como produto final. Na biodegradação de uma amostra contendo ácidos linoleico, oleico, esteárico, palmítico e mirístico, esses pesquisadores observaram que os ácidos láurico, cáprico, caprílico $\left(\mathrm{C}_{8: 0}\right)$ e butírico $\left(\mathrm{C}_{4: 0}\right)$ foram detectados, em menores concentrações se comparados com o ácido acético, não sendo detectada a presença de ácido capróico $\left(\mathrm{C}_{6: 0}\right)$. Os ácidos caprílico, capróico e butírico foram detectados em estudos realizados por Rinzema et al.$^{44}$ na degradação de ácido cáprico. Nas etapas de degradação anaeróbia do ácido linoleico foi detectada a formação do ácido oleico $\left(\mathrm{C}_{18: 1}\right)$, o que mostra que o ácido linoleico antes de sofrer a reação de $\beta$-oxidação foi hidrogenado, reduzindo o número de insaturações. Em seguida, o ácido oleico foi degradado para a formação do ácido palmitoleico e, posteriormente, ácido palmítico. Os ácidos palmítico e mirístico foram degradados em concentrações estequiométricas, equivalentes a 85-93\% molar de ácido linoleico adicionado. Esses pesquisadores concluíram que estes ácidos permaneceram recalcitrantes por um período de 60 dias.

Canovas-Diaz et al. ${ }^{45}$ observaram que o ácido mirístico, adicionado em concentrações superiores a 1.000-3.000 mg/L, necessitava de um período de 80 dias para sua degradação e o ácido mirístico formado pela reação de $\beta$-oxidação levava 70 dias. Lalman e Bagley ${ }^{43}$ sugeriram que a baixa temperatura adotada na biodegradabilidade anaeróbia de ácido linoleico, $21{ }^{\circ} \mathrm{C}$, foi um importante fator na desaceleração da biodegradação desse composto. A degradação de ácidos acético, propiônico e butírico, em sistemas anaeróbios a $55^{\circ} \mathrm{C}$, foi completamente interrompida na presença de 100-200 mg/L de ácido oleico e $500 \mathrm{mg} / \mathrm{L}$ de ácido esteárico ${ }^{36}$.

Os AGCL, em concentrações milimolares, podem se tornar inibidores dos microrganismos anaeróbios ${ }^{3,18,25}$, pois impedem a adsorção de microrganismos causando flotação da biomassa e impedindo a formação de grânulos de lodo em reatores anaeróbios de fluxo ascendente ${ }^{26}$. A flotação do lodo é decorrente da dificuldade de liberação de gases produzidos na digestão anaeróbia ${ }^{27}$.

A inibição depende do tipo de microrganismo, especificamente bactérias, pois as espécies metanogênicas e gram-positivas são mais vulneráveis ao efeito de inibição dos ácidos graxos, quando comparadas com as gram-negativas ${ }^{46,47}$. O comprimento da cadeia carbônica e o número de insaturações presentes nos ácidos graxos também são parâmetros de inibição para os microrganismos ${ }^{24,48}$. Ácidos graxos saturados com 12-14 átomos de carbono e ácidos insaturados com 18 carbonos são os ácidos com elevado grau de inibição ${ }^{46}$.

Algumas substâncias como albumina, goma e colesterol podem, entretanto, reduzir a toxicidade dos ácidos graxos, devido à formação de complexos que possam competir com ácidos graxos na adsorção na parede celular ${ }^{46}$. Bentonina e cálcio são outras substâncias que podem prevenir o efeito de inibição dos ácidos sobre os microrganismos, porque a bentonina tem poder floculante e o cálcio reage com os ácidos graxos formando precipitados ${ }^{36,47}$.

$\mathrm{O}$ consumo de hidrogênio por bactérias anaeróbias foi reduzido sensivelmente a $37{ }^{\circ} \mathrm{C}$ em sistemas reacionais suplementados com gordura de leite integral, contendo ácidos graxos insaturados e saturados ${ }^{36}$. Hanaki et al. ${ }^{36}$ observaram também o efeito do íon cál- 
cio na redução do efeito de inibição dos AGCL e concluíram que a adição desse íon reduziu a fase "lag" dos microrganismos, fase de adaptação dos microrganismos ao meio, devido à formação de compostos insolúveis, Ca-AGCL. O precipitado reduz o efeito de inibição, pois diminui a concentração de ácidos graxos livres, facilitando a adsorção desses ácidos na parede celular microbiana e, conseqüentemente, um aumento no rendimento de produção de biogás $\left(\mathrm{CH}_{4} \mathrm{e}\right.$ $\mathrm{CO}_{2}$ ). Esses autores utilizaram, como fonte de cálcio, os compostos $\mathrm{CaCl}_{2}$ e $\mathrm{CaCO}_{3}$. A adição de $\mathrm{CaCl}_{2}$ proporcionou bons resultados por ser um composto solúvel em água, ao contrário do carbonato que é insolúvel, não se dissociando em íons $\mathrm{Ca}^{+2}$.

Koster $^{49}$ pesquisou a influência dos AGCL e dos íons $\mathrm{Ca}^{+2}$ sobre uma população de bactérias metanogênicas. $\mathrm{O}$ ácido láurico $\left(\mathrm{C}_{12: 0}\right)$ foi utilizado como padrão devido ao elevado potencial de inibição à atividade metanogênica e por ser um dos principais ácidos graxos encontrados em águas residuárias ${ }^{48}$. Em uma concentração de 7,5 mM de laurato de sódio, foi observada uma inibição de $94 \%$ da atividade metanogênica. Para esse meio de cultura foi utilizado acetato de sódio como fonte de carbono. Após 3 e 20 min de exposição dos microrganismos metanogênicos ao composto laurato de sódio, houve um decréscimo de 40 e $67 \%$, respectivamente, da atividade metanogênica inicial. Por um período de $6 \mathrm{~h}$, apenas $4 \%$ da atividade metanogênica inicial permaneceu inalterada. A adição de íon $\mathrm{Ca}^{+2}$, após o período de $6 \mathrm{~h}$ de exposição, não recuperou a atividade metanogênica inicial.

$\mathrm{O}$ efeito de inibição dos precipitados de AGCL na atividade microbiana foi estudado por Särner ${ }^{50}$ e Sayed et al. ${ }^{18}$, que concluíram que esses precipitados estão relacionados com as limitações de transportes de substratos solúveis para a biomassa, devido ao fenômeno de encapsulação de grânulos de lodo. A porção hidrofóbica dos AGCL interage com a parede celular microbiana, ocasionando um decréscimo na capacidade de degradação desses substratos.

\section{UTILIZAÇÃO DE ENZIMAS EM TRATAMENTO DE ÁGUAS RESIDUÁRIAS}

A utilização de enzimas no tratamento de despejos industriais foi proposta em $1930^{51}$. Entretanto, só recentemente seu desenvolvimento como alternativa ao tratamento convencional de efluentes tem despertado grande interesse de pesquisa, em função das vantagens apresentadas, entre as quais podem ser citadas ${ }^{52}$ : a taxa de introdução no ambiente de poluentes orgânicos estranhos aos microrganismos e recalcitrantes tem aumentado, o que diminui as possibilidades de se realizar um tratamento convencional biológico ou químico que seja eficiente; há um crescente reconhecimento da capacidade das enzimas para atuar sobre poluentes específicos no tratamento e avanços recentes na biotecnologia permitiram a produção de algumas enzimas técnica e economicamente viáveis, devido ao desenvolvimento dos procedimentos de isolamento e de purificação de microrganismos.

Enzimas são catalisadores biológicos e seu uso no tratamento de efluentes apresenta várias vantagens potenciais, tais como simplicidade e facilidade no controle do processo; não há necessidade de aclimatação de biomassa; não há efeitos de choque por carga de poluentes; podem ser aplicadas em processos com baixa ou alta concentração de poluentes e operam em amplas faixas de $\mathrm{pH}$, temperatura e salinidade ${ }^{52}$.

Entre várias possibilidades, os biocatalisadores podem ser usados no tratamento de efluentes gerados nas indústrias petrolífera, têxtil, de papel e derivados de celulose e alimentícias em geral, como mostrado na Tabela 4.

A indústria do petróleo é responsável pela geração de grandes quantidades de borras oleosas, que representam um considerável dano ambiental. Essas borras consistem de um sistema multifásico con- tendo óleo, água e sólidos em suspensão, sendo, portanto, de difícil degradação microbiana. A presença de hidrocarbonetos poliaromáticos dificulta a biodegradação deste resíduo. Existem vários tipos de tratamentos, tais como incineração, aterro, biotratamento, entre outros, mas em alguns casos, os microrganismos não são capazes de suportar a toxicidade do resíduo, sendo necessário um processo alternativo. Assim, a biodegradação dos hidrocarbonetos aromáticos pode ser realizada pelo uso de enzimas oxidativas, como as peroxidases e desidrogenases ${ }^{86}$.

$\mathrm{Na}$ indústria de papel e derivados de celulose, vários estudos estão sendo desenvolvidos com o objetivo de viabilizar a utilização de microrganismos e enzimas ligninolíticas no tratamento de efluentes gerados na etapa de branqueamento, reduzindo o teor de compostos organoclorados das águas residuárias ${ }^{75,82,83}$. Similarmente, diversas propostas para tratamento de efluentes gerados na indústria têxtil, empregando as enzimas lacases e catalases, estão em fase avançada de estudos ${ }^{87}$.

Nesse mesmo setor, nos últimos anos, a aplicação de enzimas para a remoção de depósitos nas máquinas de produção de papel vem aumentando consideravelmente. Os contaminantes são proteínas, lipídeos, ceras e materiais lignocelulósicos. Os componentes orgânicos dos depósitos incluem moléculas de açúcares dos extratos de madeira e amidos. A aplicação de enzimas, como celulases, proteases, lipases e lignases, remove esses sólidos e melhora o volume de recirculação da água, impedindo a utilização de materiais poluentes como álcalis e ácidos e, com isto, reduzindo os impactos ambientais nas estações de tratamento de águas residuárias ${ }^{88}$.

Outro exemplo potencial é o uso da enzima tirosinase na remoção de compostos fenólicos presentes em águas residuárias de diversas atividades industriais, como mineração de carvão, refino de petróleo, curtimento e acabamento de couro, entre outras ${ }^{89}$.

Finalmente, ressalta-se o emprego crescente da enzima lipase na limpeza de filmes gordurosos 22 , na biodegradação de poliésteres e blendas poliméricas como poli( $\varepsilon$-caprolactona) e poli(acetato de vinila $)^{90}$ e no pré-tratamento de efluentes contendo elevados teores de lipídeos 3,22, 29,30,91,92.

O uso de enzimas em biocatálise ambiental vem ao encontro da forte tendência dos governos atuais de intensificar as restrições à poluição ambiental. No caso brasileiro, o controle ambiental é ainda mais relevante à preservação dos ecossistemas que, em função da sua extensão e biodiversidade, constituem um ativo de valor incalculável, além de garantir a representatividade nacional no cenário mundial.

\section{APLICAÇÃO DE LIPASES NO TRATAMENTO DE EFLUENTES RICOS EM LIPÍDEOS}

Os microrganismos hidrolisam os triacilglicerídeos em meio extracelular, por ação de lipases, produzindo ácidos graxos e glicerol. As lipases (triacilglicerol acil hidrolases, E.C.3.1.1.3) compreendem um grupo de enzimas hidrolíticas que atuam na interface orgânicaaquosa, catalisando a hidrólise de ligações éster-carboxílicas, presentes em acilgliceróis ${ }^{2}$.

Essas enzimas clivam triacilgliceróis específicos, entretanto, podem não ser totalmente específicas e catalisar as reações de hidrólise de triacilglicerídeos que contêm, em sua composição, diferentes ácidos graxos, o que pode ser de grande interesse para o tratamento de efluentes com alto teor de gordura ${ }^{2}$.

As lipases vêm sendo usadas na remoção de gorduras de aeradores de estações de tratamento que empregam lodo ativado ${ }^{93}$. Esta camada de gordura impede a transferência de oxigênio, comprometendo a reposição de oxigênio necessário à biomassa na degradação da matéria orgânica. A empresa japonesa Meito Sangyo Co. vem produzindo lipase de Candida rugosa (Lipase-MY), que é empregada em 
Tabela 4. Enzimas com potenciais aplicações em tratamento de efluentes

\begin{tabular}{|c|c|c|}
\hline Enzimas e Fontes & Poluentes e efluentes & Ref. \\
\hline Azorredutase (Pseudomonas luteola) & Indústrias de tintas & 53 \\
\hline \multirow[t]{2}{*}{ (Trichoderma harzianum) } & Polpa de açúcar de beterraba & 51 \\
\hline & Pré-tratamento termoquímico de celulignina & \\
\hline Cianidase (Fusaruium solani) & Cianídio & 54 \\
\hline Cianidase hidratase (Trichoderma spp.) & Cianídio & 55 \\
\hline $\begin{array}{l}\text { Monooxigenase e Iminodiacetato deidrogenase } \\
\text { (gêneros Chelatobacter e Chelatococcus) }\end{array}$ & $\begin{array}{l}\text { Remoção de compostos derivados de ácidos aminopolicarboxilícos, } \\
\text { por ex. EDTA, em efluentes municipais }\end{array}$ & 56 \\
\hline Oxirredutases e NTA Deidrogenase (gêneros & Remoção de compostos derivados de ácidos aminopolicarboxilícos, & 57 \\
\hline Chelatobacter e Chelatococcus) & por ex. EDTA, em efluentes municipais & \\
\hline Polifosfatase e Fosfotransferase & Remoção de fosfato biológico de efluentes & 58 \\
\hline Nitrogenase (Klebsiella oxytoca) & $\begin{array}{l}\text { Remoção de excesso de lodo e proteínas em estações de tratamento } \\
\text { de efluentes }\end{array}$ & 59 \\
\hline Protease & Cianídio & 60 \\
\hline Protease pronase (Pseudomonas aeruginosa) & $\begin{array}{l}\text { Inativação de vírus bacteriófago Cox A9 de efluentes, para reutilização } \\
\text { da água }\end{array}$ & 61 \\
\hline Enzimas Oxirredutases (Pseudomonas syringae) & Remoção de compostos fenólicos e catecol & 62 \\
\hline Acetilcolinesterase e enzimas antioxidantes & Degradação de pesticidas de ambientes marinhos & 63 \\
\hline Carbaril Hidrolase (Arthrobacter sp. RC100) & Degradação de inseticidas à base de N-metilcarbamato & 64 \\
\hline Naftaleno-dioxigenase & Remoção de naftaleno & 65 \\
\hline Catalase (Bacillus sp.) & Remoção de $\mathrm{H}_{2} \mathrm{O}_{2}$ presente em efluentes de branqueamento de tecidos & 66 \\
\hline$\beta$-Glicosidase e Manganês peroxidase & Remoção de corantes azo da indústria de alimentos e da indústria têxtil & 67 \\
\hline
\end{tabular}

(Phanerochaete chrysosporium e

Pleurotus sajorcaju)

Lipase (Pseudomonas aeruginosa)

(Pancreática - PL250)

(Penicillium P4)

(Penicillium restrictum)

(Yarrowia lipolytica)

(Pseudomonas aeruginosa $L P_{602} \mathrm{e}$ Anicetobacter calcoaceticus $L P_{609}$ ) (Anicetobacter sp.)

(Candida rugosa)

(pâncreas de porco)

Lacase (Coriolus versicolor e Funalia trogii)

(Chalara (syn. Thielaviopsis) paradoxa)

(Trametes versicolor)

(Lentinula edodes)

Lacase e Manganês peroxidase (Trametes

versicolor)

(Panus triginus)

(Geotrichum sp. CCMI 1019)

(Phanerochaete flavido-alba)

Peroxidase

Lignina peroxidase (Phanerochaete

chrysosporium)

Manganês peroxidase (Phanerochaete

flavido-alba)

Peroxidase de soja

Redução do teor de lipídeos em efluentes de restaurantes

Redução do tamanho das partículas de lipídeos, de efluente de matadouros, em até $60 \%$

Redução do teor de DQO de efluente da indústria de óleo de oliva, em $60 \%$

Remoção de DQO, em termos de lipídeos, de efluente da indústria de

derivados lácteos

Redução de DQO, em até $80 \%$, de efluente da indústria de extração de óleo de oliva

Redução do teor de lipídeos e DBO de efluente

Redução do teor de lipídeos de efluentes de restaurantes

Redução do teor de lipídeos e DQO de efluentes de abatedouros de frango

Redução do teor de lipídeos e de sólidos suspensos de efluentes da indústria de derivados lácteos

Tratamento de efluentes da indústria têxtil

Remoção de compostos fenólicos da indústria de extração de óleo de oliva

Remoção de pesticidas à base de uréia , N',N'-(dimetil)-N-(2-hidroxifenil) uréia (2-HF)

Remoção de compostos fenólicos, polifenóis e orto-difenóis, da indústria de extração de óleo de oliva

Remoção de hidrocarbonetos aromáticos 
estações de tratamento de efluentes nos Estados Unidos, para a remoção de gorduras em equipamentos ${ }^{94}$. O tempo de vida útil de equipamentos industriais e de estações de tratamento de efluentes elevase com a remoção de sólidos, como gorduras.

As lipases podem ser utilizadas diretamente na forma bruta (caldo fermentado) ou isoladas para promover um pré-tratamento do efluente antes da digestão anaeróbia. Entretanto, estudos têm sido realizados para verificar a possibilidade de cultivo de microrganismos produtores de lipases do gênero Penicillium em associação com a digestão do efluente de extração de azeite de oliva ${ }^{68}$.

Um complexo enzimático contendo hidrolases, como proteases, amilases, celulases e lipases, produzidas por Bacillus subtilis, foi testado em efluentes ricos em lipídeos por Cail et al. ${ }^{95}$. O pré-tratamento enzimático aumentou a remoção de DQO de $59 \%$ no controle para $78 \%$ no reator anaeróbio e reduziu os teores de lipídeos e sólidos de 47 para $70 \%$ e de 34 para $70 \%$, respectivamente.

Um pré-tratamento enzimático de efluentes de matadouro foi realizado por Masse et al. ${ }^{3}$ empregando três preparações de lipases de fontes animal, lipase pancreática 250 (PL-250, Genencor International, Rochester, NY), microbiana de Mucor miehei G-1000 (LG-1000 Genencor International, Rochester, NY) e vegetal, denominada "EcoSystem Plus" (ESP, Neozyme International, Newport Beach, CA), para avaliação da redução de DQO e do tamanho de partículas de lipídeos. Os resultados obtidos mostraram que a lipase pancreática PL-250 foi mais eficiente que as demais, com uma redução no tamanho das partículas de lipídeos em até $60 \%$, em um período de 4 h. Por outro lado, os autores não obtiveram redução significativa de DQO devido ao fenômeno de dessorção/adsorção da lipase na superfície das partículas de lipídeos.

A espécie Penicillium P4, isolada de um efluente da indústria de óleo de oliva, foi estudada para a biodegradação deste efluente, contendo $114.000 \mathrm{mg} / \mathrm{L}$ de DQO ${ }^{75}$. Após 20 dias de incubação, a $28{ }^{\circ} \mathrm{C}$, observou-se uma redução de $61 \%$ na DQO inicial do efluente.

O crescimento da levedura Yarrowia lipolytica da linhagem ATCC 20255 em efluentes da indústria de óleo de oliva, utilizando lipídeos e açúcares como fontes de carbono, foi estudado por De Felice et $a l{ }^{30}$. Após um período de $24 \mathrm{~h}$, em sistema aeróbio, a redução de DQO foi de $80 \%$ e a concentração de biomassa aumentou em 22,45 $\mathrm{g} / \mathrm{L}$. Resultados similares foram descritos por Scioli e Vollaro ${ }^{70}$.

Uma cultura mista de bactérias das linhagens Pseudomonas aeruginosa $\mathrm{LP}_{602}$, Bacillus sp. $\mathrm{B}_{304}$ e Anicetobacter calcoaceticus $\mathrm{LP}_{609}$ foi testada no tratamento de efluentes ricos em lipídeos por Mongkolthanaruk e Dharmisthiti ${ }^{22}$. Nesses testes, a linhagem $\mathrm{B}_{304}$ foi responsável pela produção das enzimas protease e amilase e as linhagens $\mathrm{LP}_{602} \mathrm{e} \mathrm{LP}_{609}$, pela de lipases. Os valores de DBO e teor de lipídeos, empregando o consórcio bacteriano, foram reduzidos, respectivamente, de 3.500 e $20.000 \mathrm{mg} / \mathrm{L}$, para valores inferiores a $20 \mathrm{mg} / \mathrm{L}$, sob condições aeróbias, num período de 12 dias.

A remoção de lipídeos de efluentes gerados em restaurantes foi verificada por Wakelin e Forster ${ }^{71}$ empregando culturas puras das espécies Anicetobacter sp., Rhodococcus rubra, Nocardia amarae, Microthrix parvicella, uma cultura mista chamada MC1 e lodo ativado aclimatado e não-aclimatado. A espécie Anicetobacter sp. foi a mais eficiente das culturas puras, removendo 60-65\% do teor de lipídeos, com uma concentração inicial de $8000 \mathrm{mg} / \mathrm{L}$. A eficiência de remoção de lipídeos do efluente pela cultura mista MC1 foi de $73 \%$. Em lodo ativado aclimatado, foram obtidas eficiências de remoção de lipídeos superiores a 90\%. Esse valor não foi observado para lodo não-aclimatado. Para todos os meios de cultura a fase "lag", fase de adaptação ao meio, foi de aproximadamente 1 dia, exceto para o lodo ativado aclimatado. Os testes de biodegradabilidade de lipídeos foram efetuados em período de 7-8 dias. A ausência desta fase "lag", para o lodo ativado aclimatado, resultou em maior remo- ção de lipídeos e um rápido crescimento dos microrganismos do meio de cultura, devido à maior assimilição do substrato pelos microrganismos.

A hidrólise enzimática com lipases produzidas pelo Penicillium restrictum, anterior à etapa biológica em um reator de lodos ativados de batelada seqüencial para o tratamento de efluentes de laticínios, foi investigada por Jung et al. ${ }^{93}$. A hidrólise do efluente foi conduzida com $0,2 \%(\mathrm{p} / \mathrm{v})$ de torta de babaçu fermentada com atividade lipásica de $11 \mathrm{U} / g$ de sólido. Uma unidade de atividade lipolítica (U) foi definida, pelos autores ${ }^{93}$, como a quantidade de enzima que libera $1 \mu \mathrm{mol}$ de ácido graxo por min, a $30^{\circ} \mathrm{C} \mathrm{e} \mathrm{pH} \mathrm{7,0.} \mathrm{Diferentes} \mathrm{concen-}$ trações de lipídeos foram avaliadas (400, 600 e 800 mg/L). Os reatores foram alimentados com efluente bruto (controle) ou hidrolisado e operaram à temperatura ambiente e com tempo de retenção hidráulica de 24 h. Até a concentração de $600 \mathrm{mg} / \mathrm{L}$, a flora microbiana assimilou a carga orgânica introduzida em ambos reatores. A partir de $800 \mathrm{mg} / \mathrm{L}$, a eficiência de remoção de DQO no reator controle decresceu, chegando a ser nula, enquanto no reator alimentado com o hidrolisado se manteve acima de $90 \%$.

A hidrólise de lipídeos de efluentes gerados em frigoríficos avícolas, empregando lipase microbiana de Candida rugosa foi realizada por Pereira et $a l^{72}$. As porcentagens de hidrólise mais elevadas foram alcançadas em efluentes tamponados no $\mathrm{pH}$ ótimo de atuação dessa preparação enzimática ( $\mathrm{pH} 7,0)$. Verificou-se a influência das concentrações de enzima, agente emulsificante e íons cálcio no desempenho da hidrólise dos lipídeos, por um período de $3 \mathrm{~h}$, por meio de um planejamento fatorial. A porcentagem de hidrólise máxima obtida foi de $20,9 \%$, com influência significativa, em níveis máximos, das concentrações de enzima $(0,4 \%)$ e agente emulsificante (3\%). O ajuste do $\mathrm{pH}$ do efluente com soluções de $\mathrm{NaOH}$ ou $\mathrm{NaHCO}_{3}$ em substituição à solução tampão e após $12 \mathrm{~h}$ de tratamento, elevou a porcentagem de hidrólise dos lipídeos para $35 \%$. A eficiência do pré-tratamento enzimático, verificada por meio de testes de atividade metanogênica, revelou uma redução no tempo de digestão anaeróbia da ordem de $33 \%$.

Preparações de lipases pancreáticas de procedências nacional (pancreatina Kin Master-LKM/RS-Brasil) e importada (pancreática Sigma, Tipo II-LPP) foram utilizadas na hidrólise de lipídeos contidos no soro de queijo ${ }^{73}$. Diferentes condições experimentais foram testadas para verificar a influência da concentração do agente emulsificante, íons cálcio e ajuste de $\mathrm{pH}$ na formação de ácidos graxos e as preparações enzimáticas utilizadas obtiveram desempenhos bastante similares, resultando em porcentagem de hidrólise da ordem de $23 \%$. A lipase de procedência nacional resultou em melhor relação custo/benefício, por ser 3 vezes mais barata que a importada.

São também conhecidos diversos documentos de patentes que tratam de maneira diversificada a aplicação de enzimas hidrolíticas, principalmente lipases, na hidrólise de compostos orgânicos contidos em águas residuárias, dentre os quais destacam-se:

A patente desenvolvida por Tschocke ${ }^{96}$ relata um procedimento para a degradação de lipídeos, contidos em caixas de gorduras de efluentes domésticos, pela adição de bactérias produtoras de lipases. Essas bactérias são fixadas e confinadas em um material suporte nãobiodegradável e imersas na superfície das caixas de gordura, obtendo porcentagem de hidrólise superior a $90 \%$.

Um método de tratamento para efluentes com elevados teores de lipídeos e/ou materiais amiláceos, fécula, a partir de um bioaditivo constituído de diversas linhagens microbianas é relatado por Gardon e Lebesgue ${ }^{97}$. Esse bioaditivo é produzido por fermentação aeróbia, de culturas enriquecidas com as espécies microbianas Aerobacter aerogenes, Bacillus subtilis, Cellulomonas biazotea, Nitrosomonas sp., Nitrobacter winogradskyi, Pseudomonas desnitrificans, Pseudomonas stutzeri e Rhodopseudomonas palustris, sais mine- 
rais, substrato e água, com controle de oxigênio e reciclagem permanente do conteúdo do fermentador. A cultura obtida é transferida para uma caixa de gordura aerada, que possui elementos de biofixação, em seu interior, para facilitar a eliminação de produtos inibidores da fermentação. A concentração de bactérias na caixa de gordura é controlada pela vazão de alimentação proveniente do fermentador e geralmente é mantida entre $10^{7}$ a $10^{10}$ bactérias $/ \mathrm{mL}$, por um período de 12 a 72 h, sob concentração de oxigênio de 4 a 8 ppm.

O emprego de uma formulação composta por emulsificantes e enzimas protease, amilase, lipase, celulase e pectinase, para a separação de lipídeos de águas de lavagem de máquinas industriais, é relatado pela patente de $\mathrm{Pat}^{98}$. Esse complexo enzimático é empregado na forma comercial (Amerzyme-A-100, Applied BiochemistsE.U.A) ou em diferentes combinações. As espécies microbianas contidas nesse complexo enzimático são Bacillus subtilis, produtoras de protease e amilase, e Aspergillus niger, produtoras de lipase, celulase e pectinase. As enzimas são aplicadas em concentrações que variam entre 1 e 200 ppm.

O processo descrito por Bruno ${ }^{99}$ refere-se a uma formulação pulverizada de bactérias/enzimas para o tratamento de rejeitos orgânicos contidos em fossas sépticas, boeiros, latões de lixo e tubulações de esgotos por meio de digestão biológica. Essa formulação é composta por enzimas, estabilizantes e ativadores de enzimas, bactérias aeróbias e anaeróbias não patogênicas do gênero Bacillus, nutrientes, tampões, emulsificantes e agentes quelantes para a remoção de metais pesados. Proporções menores que $26 \%$, em peso, são recomendadas de acordo com o tipo de rejeito.

A patente desenvolvida por Mar e Marius ${ }^{100}$ refere-se ao tratamento de rejeitos contendo amido e lipídeos, provenientes da indústria de alimentos. Esses rejeitos são subprodutos fora da especificação para consumo humano, mas com valor agregado. $\mathrm{O}$ amido pode ser reaproveitado industrialmente e o conteúdo de lipídeos, removido por meio de um tratamento enzimático empregando lipases.

O documento de patente depositado por Cammarota et al. ${ }^{69}$ refere-se à utilização de hidrolases, lipase, protease e amilase produzidas pelo fungo Penicillium restrictum em fermentação semi-sólida de rejeitos da indústria de óleo de babaçu, para tratamento anaeróbio de efluentes com uma concentração de lipídeos que varia entre 180$1200 \mathrm{mg} / \mathrm{L}$. A aplicação de enzimas hidrolíticas, anterior ao tratamento anaeróbio, resultou no aumento de remoção de DQO de 1,34,2 vezes, em relação ao efluente bruto. Esse preparado enzimático é utilizado também na limpeza de fossas sépticas, caixas de gorduras residenciais e de estabelecimentos comerciais e recuperação de reatores aeróbios e anaeróbios.

Desta forma, pode-se afirmar que a enzima lipase tem uma grande potencialidade para o tratamento de efluentes gordurosos tendo em vista sua grande especificidade e capacidade de hidrolisar os lipídeos presentes nesses efluentes.

Para viabilizar economicamente este tipo de tratamento, alguns pontos de natureza técnica devem ser considerados. É necessário conhecer em detalhes os processos industriais responsáveis pela produção dos efluentes: suas variações ao longo do tempo, os insumos empregados, o regime de descarga dos efluentes, o procedimento para limpeza das instalações, sua freqüência e produtos utilizados para esse fim. Todos esses detalhes operacionais podem influenciar na qualidade dos efluentes. É necessário também fazer uso de preparações enzimáticas ativas e otimizar as condições adequadas de hidrólise.

\section{FATORES QUE INTERFEREM NO PROCESSO DE HIDRÓLISE DE LIPÍDEOS}

A hidrólise de ésteres de triglicerídeos ocorre por clivagem seqüencial dos grupos acila no glicerídeo, de tal forma, que num dado momento, a mistura reacional contém não somente triglicerídeo, água, glicerol e ácidos graxos, como também diacilgliceróis e monoacilgliceróis ${ }^{101}$, conforme mostrado na Figura 3.

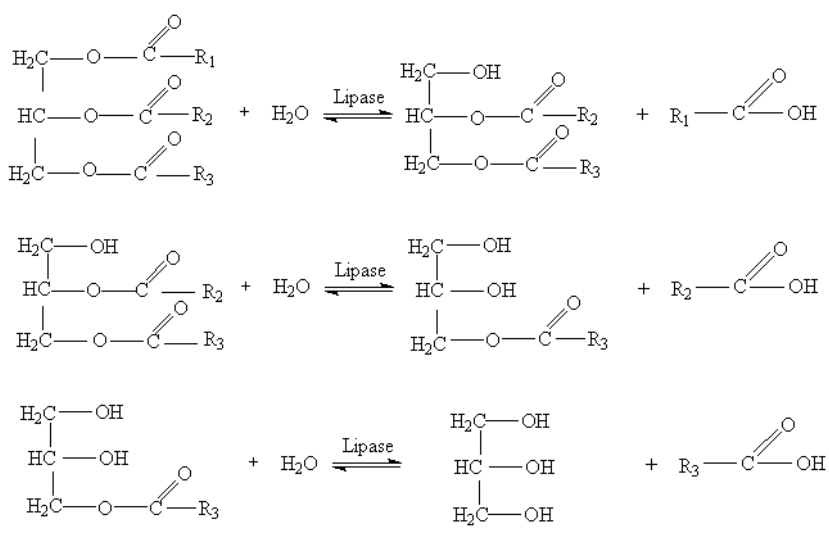

Figura 3. Hidrólise seqüencial dos grupos acila no glicerídeo, catalisada por lipases. Adaptada das ref. 101 e 102

As lipases requerem uma ativação interfacial para sua total atividade catalítica, cujo mecanismo foi estabelecido originalmente por Sarda e Desnuelle ${ }^{103}$. A interface é considerada como uma superfície imaginária que separa duas fases fisicamente distintas, a qual corresponde em nível molecular a um grupo de duas camadas adjacentes de moléculas ordenadas: uma de natureza mais hidrofóbica e outra, mais hidrofílica.

Várias hipóteses têm sido propostas para explicar a ativação nas interfaces, incluindo: uma mudança conformacional induzida interfacialmente, gerando uma enzima mais ativa (isso é explicado pelo fato de que, nos sítios ativos de adsorção na interface, a lipase assume uma nova conformação espacial); maior concentração do substrato local; uma orientação mais favorável do substrato; um menor grau de hidratação do substrato, tendo em vista que a hidratação das moléculas de lipídeos representa uma proteção às ligações éster.

$\mathrm{O}$ requerimento de uma interface (independente de sua natureza) é crítico. Mesmo em presença de solventes hidrofóbicos existe uma pequena quantidade de água ao redor da estrutura da enzima e essa camada de hidratação no sítio ativo fornece a interface necessária local para a ativação da lipase. É importante ressaltar que a atividade catalítica das lipases é sensivelmente reduzida na ausência de uma interface, o que é evidenciado pela baixa conversão na hidrólise de ésteres solúveis em água por elas catalisadas.

Portanto, uma das principais dificuldades na compreensão do mecanismo da lipólise é devida ao fato da atividade das lipases depender fortemente de como os substratos lipofílicos são apresentados à enzima, isto é, é necessário estabelecer as propriedades físicas da emulsão ${ }^{104}$.

Desta forma, o processo de hidrólise enzimática necessita de dois requisitos para a operação: a formação de uma interface lipídeo/água e a absorção da enzima nesta interface. Assim, quanto maior a interface, maior será a quantidade de enzima adsorvida, acarretando taxas de hidrólise mais elevadas.

Diferentes parâmetros podem influenciar o desempenho da hidrólise de óleos e gorduras e, conseqüentemente, diversas técnicas têm sido utilizadas para aumentar a taxa de hidrólise usando lipases como catalisadores. Alguns aspectos estudados são ${ }^{105}$ : relação fase aquosa/fase oleosa, eventual ação inibitória dos produtos formados, efeito do íon cálcio nas taxas de reação, influência do tipo de agente emulsificante na cinética do processo e efeito da agitação na taxa de reação. 
A concentração inicial de reagentes determina a extensão de uma reação. Com relação à dependência da taxa de hidrólise na quantidade de água, os resultados descritos por Rooney e Weatherley ${ }^{106}$ indicam que o equilíbrio da conversão de emulsões de óleo:água nas proporções de 3:1 e 8:1 foram 90 e 72\%, respectivamente. Portanto, quanto menor a razão óleo:água, maior será a extensão da hidrólise. Uma outra forma de aumentar o grau de hidrólise é a remoção do glicerol formado no processo ${ }^{106}$.

Com relação à influência dos íons cálcio, nos trabalhos pioneiros relativos à hidrólise enzimática de óleos, Benzonana e Desnuelle ${ }^{107}$ estudaram o efeito de íons sobre a velocidade de reação. Em pesquisas mais recentes ${ }^{92}$ alguns aspectos importantes sobre esse tema foram elucidados, comprovando a importância do papel de íons, como o cálcio, sobre a atuação no centro catalítico de alguns tipos de lipases ${ }^{108}$. O íon cálcio pode estimular a catálise hidrolítica por lipases pelos seguintes mecanismos: pela ativação da lipase por meio da alteração da conformação da enzima; pelo aumento da adsorção da lipase na interface óleo/água, e pela remoção de ácidos graxos da interface óleo/água, de tal forma que a lipase pode agir em outras moléculas de água. Entretanto, os dados descritos na literatura são contraditórios. Enquanto alguns trabalhos descrevem o íon cálcio como agente estimulante, outros relatam sua ação inibitória. Essa inconsistência pode ser resultado das diferentes condições testadas, como $\mathrm{pH}$ e teor de cálcio, principalmente quando goma arábica é usada como agente tensoativo (cálcio é um possível contaminante de algumas preparações comerciais de goma arábica). Para concentrações de íons cálcio até $5 \mathrm{mM}$, o efeito estimulante do íon cálcio foi mais significativo para reações conduzidas em $\mathrm{pH} 7$, quando comparadas com reações realizadas em $\mathrm{pH} 5^{108}$.

Quanto ao efeito dos emulsificantes nas lipases, deve-se ter em conta que a atividade da lipase varia tanto em função do tipo de tensoativo, como da sua concentração ${ }^{109}$. Entre os tensoativos, a goma arábica e o Triton X-100 são os emulsificantes mais usados nas análises da ação lipolitíca sobre triglicerídeos ${ }^{110,111}$. Os tensoativos iônicos não são convenientes porque podem deslocar o equilíbrio iônico. Entre os tensoativos não iônicos, alguns deles como o "Tween" e o "Span" também não são adequados à determinação da atividade lipolitíca porque, em virtude de possuírem ligações éster nas suas moléculas, podem sofrer ataque por parte da lipase.

Wang et al. ${ }^{108}$ analisaram a hidrólise do óleo de oliva catalisada pela lipase de Candida rugosa em um sistema emulsificado apenas por agitação mecânica, tendo sido verificadas taxas de hidrólise similares nos sistemas reacionais na presença e ausência de emulsificante.

Os óleos e gorduras contendo ácidos graxos insaturados de cadeia longa são os principais substratos das lipases, sendo o azeite de oliva o mais utilizado na dosagem de atividade lipolítica. Esses ácidos estão também presentes em águas residuárias oriundas dos processamentos de produtos lácteos e avícolas e, de acordo com a especificidade das lipases pelo substrato, diferentes perfis de hidrólise (composição em ácidos graxos) podem ser obtidos.

Em estudos realizados por Pereira ${ }^{112}$, empregando diferentes preparações de lipase (microbiana e pancreática) para efetuar pré-tratamentos de águas residuárias de indústrias avícolas, foi observado que, de maneira geral, a lipase microbiana (Candida rugosa) libera preferencialmente o áacido oleico $\left(\mathrm{C}_{18: 1}\right)$ seguido dos ácidos esteárico $\left(\mathrm{C}_{18: 0}\right)$ e palmitoleico $\left(\mathrm{C}_{16: 1}\right)$. Por outro lado, os ácidos linoleico $\left(\mathrm{C}_{18: 2}\right)$, esteárico, oleico e palmítico $\left(\mathrm{C}_{16: 0}\right)$ são liberados preferencialmente pela enzima pancreática, seguidos por outros ácidos em menor proporção. Esse mesmo autor verificou ainda que, independente da composição em ácidos graxos contidos nos efluentes pré-tratados enzimaticamente, resultados similares foram obtidos com relação ao volume de gás metano formado nos testes de biodegradabilidade anaeróbia, revelando uma velocidade de reação 5 vezes superior em relação ao efluente bruto, demonstrando a eficiência da aplicação de lipases no pré-tratamento de águas residuárias contendo elevado teor de lipídeos.

\section{CONCLUSÃO}

Nas duas últimas décadas inúmeros melhoramentos no processo anaeróbio de efluentes de indústrias alimentícias têm sido realizados, principalmente para tratamento de águas residuárias da produção de açúcar, amido e cerveja. Entretanto, para alguns efluentes contendo elevados teores de óleos e gorduras, como os provenientes de frigoríficos, abatedouros, laticínios, enlatados, entre outros, a operação de reatores de digestão anaeróbia apresenta inúmeros problemas operacionais, como formação de espuma pelas camadas de lipídeos, formação de caminhos preferenciais no leito de lodo e arraste da biomassa, levando à perda da eficiência e, até mesmo, ao colapso do reator. Os reatores anaeróbios situados à jusante de unidades fabris são, portanto, suscetíveis à alimentação de efluentes com teores de gordura acima dos recomendáveis. Técnicas para melhorar a eficiência dos biodigestores, incluem instalação de caixas de gordura ou flotadores, tratamentos com adição de álcalis ou enzimas específicas como as hidrolases, principalmente as lipases cuja função biológica é a hidrólise de ligações éster carboxílicas, presentes em acilgliceróis, com conseqüente liberação de ácidos graxos e glicerol. A adição da enzima lipase pode aumentar significativamente a eficiência deste processo, reduzindo os impactos ambientais gerados sobre os recursos hídricos, considerados atualmente como um recurso natural limitado, dotado de valor econômico. O emprego dessa técnica permite uma redução dos níveis de sólidos suspensos, lipídeos e proteínas, o que possibilita melhores condições de operação no tratamento anaeróbio. Uma outra grande vantagem em se utilizar enzimas hidrolíticas, especificamente lipases, é a desobstrução de filmes de óleos em tubulações, resultando no aumento da vida útil dos equipamentos.

\section{REFERÊNCIAS}

1. Omil, F.; Garrido, J. M.; Arrojo, B.; Méndez, R.; Water Res. 2003, 37, 4099.

2. Saxena, R. K.; Sheoran, A.; Giri, B.; Davidson, W. S.; J. Microbiol. Methods 2003, 52, 1.

3. Masse, L.; Kennedy, K. J.; Chou, S.; Bioresour. Technol. 2001, 77, 145.

4. Glazer, A. N.; Nikaido, H.; Microbial Biotechnology: Fundamentals of Applied Microbiology, W. H. Freeman \& Company: New York, 1995, p. 561

5. Nakhla, G.; Al-Sabawi, M.; Bassi, A.; Liu, V.; J. Harzard. Mater 2003, B102, 243.

6. Marshall, K. R.; Harper, W. J. Em Surveys in Industrial Wastewater Treatment, Food and Allied Industries; Barnes, D.; Forster, C. F.; Hrudey, S. E., eds.; Pitman Publishing Ltd: London, 1984, vol. 1, cap. 5, p. 296.

7. Ruston, B.; Water Sci.Technol. 1993, 28, 2, 67.

8. Vidal, G.; Carvalho, A.; Méndez, R.; Lema, J. M.; Bioresour. Technol. 2000, $74,231$.

9. Danalewich, J. R.; Papagiannis, T. G.; Belyea, R. L.; Tumbleson, M. E.; Raskin, L.; Water Res. 1998, 32, 3568.

10. Harper, W. I.; Food Technol. 1974, 28, 50.

11. Yu, H. Q.; Fang, H. H. P.; Water Res. 2001, 35, 3697.

12. Cookson Jr., J. T.; Bioremediation Engineering - Design and Application, McGraw-Hill: EUA, 1995.

13. Von Sperling, M.; Princípios do tratamento biológico de águas residuárias, $2^{a}$ ed., DESA-UFMG: Belo Horizonte, 1998, cap. 4.

14. Faisal, M.; Unno, H.; Biochem. Eng. J. 2001, 9, 25.

15. Lema, J. M.; Méndez, R.; Iza, J.; Fernandezpolanco, F.; Water Sci. Technol. 1991, 24, 79.

16. Wendt, M. R.; Koetz, P. R.; Abib, E. N.; Rev. Bras. Agroc. 1999, 5, 161.

17. Koetz, P. R.; Faria, O. L. V.; Nunes, W. A.; Rev. Bras. Agroc. 1996, $2,117$.

18. Sayed, S.; Van Der Zanden, J.; Wijffels, R.; Lettinga, G.; Biol. Wastes 1988, 23, 117.

19. Liu, Y.; Xu, H. L.; Yang, S. F.; Tay, J. H.; Water Res. 2003, 37, 661.

20. Raunkjaer, K.; Hvitved-Jacobsen, T.; Nielsen, P. H.; Water Res. 1994, 8, 251. 
21. Henze, M.; Water Sci. Technol. 1992, 25, 1.

22. Mongkolthanaruk, W.; Dharmisthiti, S.; Int. Biodet. Biodeg. 2002, 50, 101.

23. Quéménuer, M.; Marty, Y.; Water Res. 1994, 28, 1217.

24. Komatsu, T.; Hanaki, K.; Matsuo, T.; Water Sci.Technol. 1991, 23, 1189.

25. Hwu, C. -S.; Tseng, S. -K.; Yuan, C. -Y.; Kulik, Z.; Lettinga, G.; Water Res. 1998, 32, 1571.

26. Alves, M. M.; Vieira, J. A. M.; Pereira, R. M. A.; Pereira, M. A.; Mota, M.; Water Res. 2001, 35, 255.

27. Petruy, R.; Lettinga, G.; Bioresour. Technol. 1997, 61, 141.

28. Mendes, A. A.; Freitas, L.; Castro, H. F.; Resumos do VI Seminário Brasileiro de Tecnologia Enzimática, Rio de Janeiro, Brasil, 2004.

29. Dharmisthiti, S.; Kuhasuntisook, B.; J. Ind. Microbiol. Biotechnol. 1998 21, 587.

30. De Felice, B.; Pontecorvo, G.; Carfagna, M.; Acta Biotechnol. 1997, 17, 231.

31. Hawkes, F. R.; Donnely, T.; Anderson, G. K.; Water Res. 1995, 29, 525.

32. Dueholm, T. E.; Andreasen, K. H.; Nielsen, P. H.; Water Sci. Technol. 2001, 43, 165.

33. Andreasen, K.; Nielsen, P. H.; Water Res. 2000, 34, 1559.

34. Angelidaki, I.; Ahring, B. K.; Appl. Environ. Microbiol. 1995, 37, 808.

35. Novak, J. T.; Carlson, D.; J. Water Pollut. Control Fed. 1970, 42, 1932.

36. Hanaki, K.; Matsuo, T.; Nagase, M.; Biotechnol. Bioeng. 1981, 23, 1591.

37. Angelidaki, I.; Ahring, B. K.; Appl. Microbiol. Biotechnol. 1992, 37, 808

38. Salminen, E.; Rintala, J.; Bioresour. Technol. 2002, 83, 13.

39. Pavlostathis, S. G.; Giraldo-Gomez, E.; Water Sci. Technol. 1991, 24, 35.

40. Lin, J.- G.; Chang, C.- N.; Chang, S.- C.; Bioresour. Technol. 1997, 62, 85

41. Perle, M.; Kimchie, S.; Shelef, G.; Water Sci. Res. 1995, 29, 1549.

42. Weng, C. -N.; Jerris, J. S.; Water Res. 1976, 10, 9

43. Lalman, J. A.; Bagley, D. M.; Water Res. 2000, 34, 4220.

44. Rinzema, A.; Boone, M.; Van Knippenberg, K.; Lettinga, G.; Water Environ Res. 1994, 66, 40.

45. Canovas-Diaz, M.; Sanchez-Roig, M. J.; Iborra, J. L. Em Biomass for Energy, Industry and Environment.; $6^{\text {th }}$ E. C. Conference; Grassi, G.; Collina, A.; Zibetta, H., eds.; Elsevier Applied Science: London, 1991.

46. Nieman, C.; Bact. Rev. 1954, 18, 147.

47. Roy, F.; Albagnac, G.; Samain, E.; Appl. Environ. Microbiol. 1985, 49, 702

48. Koster, I. W.; Cramer, A.; Appl. Environ. Microbiol. 1987, 53, 403.

49. Koster, I.W.; Biol. Wastes 1987, 22, 295.

50. Särner, E.; Water Res. 1981, 15, 671.

51. Aitken, M. D.; Chem. Eng. J. 1993, 52, B.49.

52. Karam, J.; Nicell, J. A.; J. Chem. Technol. Biotechnol. 1997, 69, 141.

53. Chen, B.- Y.; Process Biochem. 2002, 38, 437.

54. Barclay, M.; Tett, V. A.; Knowles, C. J.; Enzyme Microb. Technol. 1998, $23,321$.

55. Ezzi, M. I.; Lynch, J. M.; Enzyme Microb. Technol. 2002, 31, 1042.

56. Bucheli-Witschel, M.; Egli, T.; FEMS Microbiol. Rev. 2001, 25, 69

57. Egli, T.; J. Biosci. Biotechnol. 2001, 92, 89.

58. Czerska, B.; Miksch, B.; Matsché, K.; Franz, A. N.; Water Sci. Technol. 1997, 36,87 .

59. Jung, J.; Xing, X.- H.; Matsumoto, K.; Biochem. Eng. J. 2002, 10, 67.

60. Kao, C. M.; Liu, J. K.; Lou, H. R.; Lin, C. S.; Chen, S. C.; Chemosphere 2003, 50, 1055 .

61. Nasser, A. M.; Glozman, R.; Nitzan, Y.; Water Res. 2002, 36, 2589.

62. Caza, N.; Bewtra, J. K.; Biswas, N.; Taylor, K. E.; Water Res. 1999, 33 3012 .

63. Lionetto, M. G.; Caricato, R.; Giordano, M. E.; Pascariello, M. F. Marinosci, L.; Schettino, T.; Mar. Pollut. Bull. 2003, 46, 324.

64. Hayatsu, M.; Mizutani, A.; Hashimoto, M.; Sato, K.; Hayano, K.; FEMS Microbiol. Lett. 2001, 201, 99.

65. Nigam, P.; Banat, I. M.; Marchant, R.; Environ. Int. 1998, 24, 671.

66. Paar, A.; Costa, S.; Tzanov, T.; Gudelj, M.; Robra, K.- H.; Cavaco-Paulo, A.; Gübitz, G. M.; J. Biotechnol. 2001, 89, 147.

67. Chagas, E. P.; Durrant, A. R.; Enzyme Microb. Technol. 2001, 29, 473

68. Robles, A.; Lucas, R.; De Cienfuegos, R.; Gálvez, A.; Bioresour. Technol. 2000, 74, 217.

69. Cammarota, M. C.; Freire, D. M. G. F.; Sant'Anna Jr., G. L.; Russo, C.; Freire, D. D. C.; Castilho, L. R.; BR PI 0,007,101-3A 2002
70. Scioli, C.; Vollaro, L.; Water Res. 1997, 31, 2520

71. Wakelin, N. G.; Forster, C. F.; Bioresour. Technol. 1997, 59, 37.

72. Pereira, E. B.; Castro, H. F.; Furigo Jr, A.; XIV Simpósio Nacional de Fermentações, Florianópolis, Brasil, 2003.

73. Mendes, A. A.; Castro, H. F.; XIV Simpósio Nacional de Fermentações, Florianópolis, Brasil, 2003.

74. Kahraman, S. S.; Gurdal, I. H.; Bioresour. Technol. 2002, 82, 215.

75. Robles, A.; Lucas, R.; Martínez-Cañamero, M.; Omar, N. B.; Pérez, R.; Gálvez, A.; Enzyme Microb. Technol. 2002, 31, 516.

76. Jolivalt, C.; Brenon, S.; Caminade, E.; Mougin, C.; Pontié, M.; J. Membr. Sci. 2000, 180, 103.

77. D’Annibale, A.; Stazi, S. R.; Vinciguerra, V.; Di Mattia, E.; Sermanni, G. G.; Process Biochem. 2000, 34, 697.

78. Edwards, W.; Leukes, W. D.; Bezuidenhout, J. J.; Desalination 2003, 149, 275.

79. Fenice, M.; Sermanni, G. G.; Federici, F.; D’annibale, A.; J. Biotechnol. 2003, 100, 77.

80. Máximo, C.; Amorimand, M. T. P.; Costa-Ferreira, M.; Enzyme Microb. Technol. 2003, 32, 145.

81. Ruiz, J. C.; De La Rubia, T.; Pérez, J.; Lopez, J. M.; FEMS Microbiol. Lett. 2002, 212, 41.

82. De La Rubia, T.; Linares, A.; Pérez, J.; Muñoz-Dorado, J.; Romera, J.; Martínez, J.; Res. Microbiol. 2002, 153, 547.

83. López, C. Mielgo, I. Moreira, M. T. Feijoo, G. Lema, J. M.; J. Biotechnol. 2002, 99, 249.

84. Akay, G.; Erhan, E.; Keskinler, B.; Algur, O. F.; J. Membr. Sci. 2002, 206, 61.

85. Seetharam, G. B.; Saville, A. B.; Water Res. 2003, 37, 436

86. Bon, E. P. S.; Pereira Jr., N., eds.; Tecnologia Enzimática: Aplicação de enzimas no meio ambiente, ENZITEC: Rio de Janeiro, 1999.

87. Costa, S. A.; Tzanov, T.; Paar, A.; Gudelj, M.; Gübitz, G. M.; Cavaco-Paulo, A.; Enzyme Microb. Technol. 2001, 28, 815.

88. Farrell, R. L.; Hata, K.; Wall, M. B.; Adv. Biochem. Eng. Biotechnol. 1997, 57, 197

89. Durán, N.; Esposito, E.; Appl. Catal., B 2000, 28, 83.

90. Sivalingam, G.; Chattopadhyay, S.; Madras, G.; Chem. Eng. Sci. 2003, 58, 2911.

91. Cammarota, M. C.; Teixeira, G. A.; Freire, D. M. G.; Biotechnol. Lett. 2001, $23,1591$.

92. Jaeger, K. E.; Reetz, M. T.; Trends Biotechnol. 1998, 16, 396.

93. Jung, F. B.; Cammarota, M. C.; Freire, D. M. G.; Biotechnol. Lett. 2002, 24, 1797.

94. Seitz, E. W.; J. Am. Oil Chem. Soc. 1974, 51, 12.

95. Cail, R. G.; Barford, J.P.; Lichacz, R.; Agric. Wastes 1986, 18, 27.

96. Tsochocke, C.; FR pat.2,659,645 1990

97. Gardon, R.; Lebesgue, Y.; FR pat. 2,684,664 1991.

98. Pat, A. M.; US pat. 5,459,066 1995.

99. Bruno, M.; US pat. 5,464,766 1995.

100. Mar, L. H. B.; Marius, V. T.; WO pat. 9,609,772 1996.

101. Haraldsson, G. G.; Mar. Lipids Biotechnol. 1991, 7, 337.

102. Castro, H. F.; Mendes, A. A.; Santos, J. C.; Aguiar, C. L.; Quim. Nova 2004, $27,146$.

103. Sarda, L.; Desnuelle, P.; Biochim. Biophys. Acta 1958, 30, 513.

104. Brockman, H.L. Em Lipases; Borgstrom, B.; Brockman, H. L., eds.; Elsevier: Amsterdam, 1984.

105. Buehler, M. E.; Wandrey, C.; Fat Sci. Technol. 1987, 89, 156.

106. Rooney, D.; Weatherley, L. R.; Process Biochem. 2001, 36, 947.

107. Benzonana, G.; Desnuelle, P.; Biochim. Biophys. Acta 1968, 164, 47.

108. Wang, Y. J.; Sheu, J. Y.; Wang, F. F.; Shaw, J. F.; Biotechnol. Bioeng. 1988, 31,628 .

109. Mozaffar, Z.; Weete, J. D.; Due, R.; J. Am. Oil Chem. Soc. 1994, 71, 75

110. Gray, C. J.; Narang, J. S.; Barker, S. A.; Enzyme Microb. Technol. 1990, 12,800 .

111. Ramos, M. C.; Gil, M. H.; Garcia, F. A. P.; Cabral, J. M. S.; Guthrie, J. T.; Biocatalysis 1992, 6, 223.

112. Pereira, E. B.; Tese de Doutorado, Universidade Federal de Santa Catarina, Brasil, 2004. 